\title{
SOME ISSUES OF EUROPEAN INTEGRATION IN THE MODERN CRIMINAL LAW OF UKRAINE
}

Timofeyeva L. Yu.

\section{INTRODUCTION}

Criminal law provides for the most severe means of influence against perpetrators. But such a means of influence must conform to the universal humanistic principles. The principles laid down in the Association Agreement and the ECtHR's practices are exactly the same. Therefore, Ukraine should take this into account in the path of European integration.

The implementation of the Association Agreement between Ukraine, on the one part, and the European Union, the European Atomic Energy Community and their member states have resulted in a set of significant changes in Ukraine. European integration trends are implemented both in general terms and in separate institutes of Criminal Law (in particular, the specifics of criminal liability).

Some issues of European integration are researched by L.A. Harbovs'kyy, N.A. Orlovska, V.V. Korniyenko, M.I. Khavronyuk, V.O. Tuliakov, K.O. Trykhlib, H.V. Yepur, O.O. Zhytnyy etc. However, there are still many outstanding issues, in particular, methodological ones. The first it is necessary to get closer to European values and principles.

It is very important that Ukraine and the European Union have common values (it is emphasized in the Association Agreement). There are respect for democratic principles, the rule of law, good governance, human rights and fundamental freedoms, including the rights of persons belonging to national minorities, non-discrimination of persons belonging to minorities, and respect for diversity, human dignity and commitment to the principles of a free market economy that contribute to Ukraine's participation in European politics ${ }^{1}$.

It is important that the acts of the European Union and the Council of Europe not only declare certain principles but also provide for specific mechanisms for their implementation, as well as demonstrate a response to their violation.

Human rights and fundamental freedoms (the right to life, liberty and security of person, respect for privacy and family life, prohibition of torture, slavery, etc.), which must be protected and protected worldwide,

\footnotetext{
Timofeyeva L.Yu. European integration Criminal Law policy and achievement freedom and security: collective monograph. Law and Border: Implementation of law policy in the sphere of state border security / N. Orlovska, A. Mota, R. Liashuk, L. Timofeyeva, L. Litvin, Lviv-Toruń : Liha-Pres, 2019. P. 50-67. DOI https://doi.org/10.36059/978-966-397-179-7/50-66.
} 
are enshrined in the Convention. They are fundamental, but under the influence of time their interpretation may change.

\section{Punishment and European integration}

The protection of human rights and freedoms, as well as security, enshrined as the tasks of the Criminal legislation ${ }^{2}$. According to Art. 29 Declaration, everyone has duties to the community in which alone the free and full development of his personality is possible.

The practice of the ECtHR in the case of Welch v. The United Kingdom (application no 17440/90 from 09 February 1995), based on the content of Article 7 of the European Convention for the Protection of Human Rights and Fundamental Freedoms, the court stated that "when assessing one measure or another as a "punishment", the starting point should be to determine whether its application is the result of a conviction for a "criminal offense". Other factors that may be considered significant are the nature and purpose of the measure, its definition in accordance with national law, the procedures for its application and implementation, and its rigor (paragraph 28). In this context, we are talking about the protection of human rights under the Convention in the case of applying not only punishment but also administrative penalties (Criminal Law content) ${ }^{3}$.

The concept of "criminal responsibility" is broader than the concept of punishment, because it covers not only the restrictions inherent in the types of punishments provided by Criminal Law, as well as other restrictions on the rights and freedoms of the perpetrator of crime, which are provided by the Criminal Code. It is about convicting a person found guilty of committing a crime that has a legal expression in its criminal record. The ECtHR considers that in itself a judgment finding a guilty person harms him, regardless of the adverse social consequences which he may also cause ${ }^{4}$. A person shall be criminally liable if it is found guilty

\footnotetext{
2 For example, the counter-terrorism measures are always aimed at ensuring public security. However, they limit the freedom of citizens, and in particular the right to privacy (airport checks, the installation of surveillance cameras in public places, wiretapping). This also applies to counteraction illegal tobacco transport across borders. Stanislav Filippov. The smuggling of tobacco product in Europe: criminologetic potential capacity. Baltic Journal of Law \& Politics. № 12 (1). 2019. P. 35-61, DOI: 10.2478/bjlp-2019-0002; UNDP. Institute for Economics \& Peace. Global Terrorism Index 2019: Measuring the Impact of Terrorism, Sydney (2019).URL: http://visionofhumanity.org/reports (accessed Date Month Year).

These include fines, arrest. For example Case of Shvydka v. Ukraine, The European Court of Human Rights, 30 October 2014, application no 17888/12.

4 Баулин Ю.В. О методологическом подходе к определению уголовной ответственности (на материалах Украины). Российский ежегодник уголовного права. 2012. № 6. С. 484.
} 
in the corresponding with Law order, because the procedure of criminal prosecution against the person causing her pain, violates the principles of Criminal Law (including humanity); not to mention the conviction of the innocent.

According to Art. 7 no one shall be held guilty of any criminal offence on account of any act or omission which did not constitute a criminal offence under national or international law at the time when it was committed. Nor shall a heavier penalty be imposed than the one that was applicable at the time the criminal offence was committed.

The concept of the presumption of innocence most clearly reflects the realization of the principle of humanism, both narrowly and broadly. The presumption of innocence is one of the means of restriction of the state since the times of the Grand Charter of Liberties, the Bill of Rights and the most striking manifestation of the implementation of the principle of humanism in Criminal Law, since the prosecution of a person, including the sentencing, provides for an appropriate procedure of proof. The presumption of innocence of a crime is enshrined in a number of international legal instruments, in particular the Universal Declaration of Human Rights of 1948 (Part 1, Article 11), the International Covenant on Civil and Political Rights, 1966 (Article 2, Article 14), Part 2 of Art. 6 of the Convention for the Protection of Human Rights and Fundamental Freedoms 1950, enshrined in the Constitutions of many States, the principle of the presumption of innocence becomes a constitutional principle 5 .

The presumption of innocence is represented by a number of rights and prohibitions, including the right to remain silent and not to testify against itself (nemo tenetur principle) ${ }^{6}$ as a basic requirement of justice, embodied in paragraph 1 of Art. 6 of the Convention in its criminal context. This right is conditioned by obligations Liabilities and ban infringe on the freedom of another person, namely, to force her to testify against himself. Another right that follows from this decision is the right to be heard, which is that the person must be able to explain under what circumstances he or she committed the crime and the reasons for his or her

\footnotetext{
Баулин Ю.В. О методологическом подходе к определению уголовной ответственности (на материалах Украины). Российский ежегодник уголовного права. 2012. № 6. С. 484.

6 Funke v. France, The European Court of Human Rights, 25 February 1993, application no 10828/84. URL: http://hudoc.echr.coe.int/eng?i=001-57809; Quinn v. Ireland, The European Court of Human Rights (Fourth Section), 21 December 2000, applications no 36887/97. URL: http:// hudoc.echr.coe.int/eng-press?i=003-68249-68717; Saunders v. the United Kingdom, The European Court of Human Rights, 17 December 1996, application no 19187/91. URL: http://hudoc.echr.coe. int/eng? $\mathrm{i}=001-58009$.
} 
behavior before being punished or otherwise punished. The contradiction is that criminal prosecution requires a court to pronounce a person guilty of a crime, but the institution of criminal liberation in some way overcomes the person's guilt without a court verdict and acquits him. It turns out that in this context, the manifestation of humanism is realized in violation of the principle of legality.

In order to make a decision by the court, including in the appointment of a person with criminal responsibility and other measures of Criminal Law nature, it is necessary to observe "... the balance of justice between the requirements of the public interest of the community and the requirements of protection of fundamental rights of the individual"'. The principle of a fair balance is that the court decides on the law in symbiosis with the obligations Member States under the provisions of the Convention. National authorities should balance the interests of members of society with fundamental human rights and freedoms. Both insufficient and over-implementation of the principle of humanism is undesirable, so the law it is necessary to limit both the procedure for applying repression and the application of incentive rules.

Another issue that arises is the proportionality of the Criminal Law. The general principle of proportionality (means end rational review with strict scrutiny for suspect classes) represents a key aspect of contemporary legal thought ${ }^{8}$.

For the proper application of the principle of proportionality by courts, the test of proportionality with a two-step structure is essential. In the first stage, the court must establish that power is limited to a certain right. In the second stage, the authorities must demonstrate to the court that it pursued a legitimate aim and that the restriction was proportionate to that purpose ${ }^{9}$.

The proportionality test includes three criteria: first, a tool designed to achieve the goal of power must be fit for that purpose (appropriateness); secondly, the most appropriate means should be chosen, which least restricts the right of the individual (necessity); thirdly, the loss to the individual from the restriction of his right must be proportionate to the government's

\footnotetext{
7 Alastair Mowbray. A Study of the Principle of Fair Balance in the Jurisprudence of the European Court of Human Rights. Human Rights Law Review, Volume 10, Issue 2 (2010), DOI: $10.1093 / \mathrm{hrlr} / \mathrm{ngq006.}$

8 Eric Engle. The History of the General Principle of Proportionality: An Overview. Dartmouth Law Journal № 10 (2012). P. 2. URL: http://papers.ssrn.com/sol3/papers.cfm?abstract $\mathrm{id}=1431179$.

9 Погребняк С. Принцип пропорційності у судовій діяльності. Філософія права $i$ загальна теорія права. 2012. № 2. С. 50.
} 
benefit in achieving the objective (proportionate in the narrow sense) ${ }^{10}$. Proportionality in the narrow sense is also often referred to as the principle of balance or the principle of balance of justice ${ }^{11}$.

In assessing the appropriateness of the remedy, the court must take into account the fact that there are categorically prohibited remedies (such as torture), which makes it inappropriate to further analyze certain restrictions on their proportionality. In addition, the assessment shall be legitimate goal that is pursued appropriate measure. Legitimacy must flow from the Constitution and from other legislation ${ }^{12}$. The basis of the requirement of purpose legitimacy is the view that state measures cannot be carried out without an appropriate purpose ${ }^{13}$.

According to Art. 7 the Convention nor shall a heavier penalty be imposed than the one that was applicable at the time the criminal offence was committed. Prohibition of the retroactive effect of Criminal Law is one of the manifestations of the principle of humanism in a civilized, democratic state, since, at the time of committing the act, the person must know (or have been able to know through the lawful procedure of promulgation of the provisions of the Criminal Law) about the criminal nature of such act, as well as the degree of punishment, which follows the commission of such an act. The opposite would be inhumane.

In the Case of Maktouf and Damjanovic v. Bosnia and Herzegovina no $2312 / 08$ and $34179 / 08$ from 18 July $2013^{14}$ the ECtHR interprets the possibility of applying the retroactive effect of Criminal Law as one of the manifestations of the principle of humanism and the impossibility of applying it to a person who has committed a serious violent crime against humanity. Bosnia and Herzegovina court found Maktouf guilty and sentenced in 2003 the Criminal Code of Bosnia and Herzegovina for aiding and abetting the capture of two civilian hostages - a war crime committed during the 1992-95 war by imprisonment for a term of 5 years,

10 Коэн-Элия М., Порат И. Американский метод взвешивания интересов и немецкий тест на пропорциональность: исторические корни. Сравнительное конституционное обозрение. 2011. № 3. С. 61.

11 Погребняк С. Принцип пропорційності у судовій діяльності. Філософія права і загальна теорія права. 2012. № 2. С. 16, 52.

12 Шлинк Б. Пропорциональность: к проблеме баланса фундаментальных прав и общественных целей. Сравнительное конституционное обозрение. 2012. № 2 (87). С. 61.

13 Peter-Alexis Albrecht. The Forgotten Freedom: September 11 as a Challenge for European Legal Principles. Berlin : BWV Berliner Wissenschafts-Verlag. 2003, 68.

14 Maktouf and Damjanović v. Bosnia and Herzegovina, The European Court of Human Rights, 18 July 2013, applications no 2312/08 and 34179/08. URL: http://hudoc.echr.coe.int/sites/eng/ pages/search.aspx?i=001-12271. 
applying a reduction provision punishment. According citizen Maktouf Criminal Code in 1976, which operated at the time of the crime, involves more of sanctions, despite the fact that, sanctions was provided for the death penalty. But we cannot say that any applicant could get more of punishment subject to the application of the Criminal Code in 1976, the most important is that citizen Maktouf was possible to assign more of punishment than that which was intended. Punishment was appointed following penalties below the article of the Criminal Code in 1976 was not softer minimum sentence CC 2003 application declared inadmissible (manifestly ill-founded). CC 1976 Bosnia and Herzegovina cannot be regarded as a softer law.

The law on criminal liability, which repeals the criminality of an act or mitigates criminal liability, shall be retroactive in time that shall apply to persons who had committed relevant act before that law entered into force, including the persons serving their sentence or those who have completed their sentence but have a conviction.

The Part 2 of Article 7 of the Convention, which provides that this article shall not constitute an obstacle to the judicial punishment of any person for any act or omission which, at the time of their commission, constituted a criminal offense in accordance with the general principles of law recognized by civilized countries.

All of these principles also apply to particular categories of persons, including minors.

\section{Juvenile justice}

In particular, according to the United Nations Standard Minimum Rules for the Administration of Juvenile Justice (Beijing Rules) of 29 November 1985, "Member States shall endeavor to develop conditions that will ensure for the juvenile a meaningful life in the community, which, during that period in life when she or he is most susceptible to deviant behavior, will foster a process of personal development and education that is as free from crime and delinquency as possible"15.

Also, in accordance with paragraph 10 of General Comment No. 10 (2007) of the UN Committee on the Rights of the Child, "The rights of the child in the system of justice for children" is an example where the best interests of the child are the practice where traditional criminal justice goals, such as punishment, give way to rehabilitation and the restorative goals of offender justice.

\footnotetext{
15 United Nations Standard Minimum Rules for the Administration of Juvenile Justice (The Beijing Rules) Adopted by General Assembly resolution 40/33 of 29 November 1985. URL: https://www.un.org/ruleoflaw/files/UNAdminofJJUSTICE.pdf.
} 
In other words, international standards indicate that a juvenile justice system should be the basis of criminal justice policy against juvenile offenses. This system is focused on the application of alternative and noncriminal sanctions (warning, reprimand, restitution and compensation) ${ }^{16}$.

According to the United Nations Guidelines for the Prevention of Juvenile Delinquency: The Riyadh guidelines (A/RES/45/112) from 14 December 1990 prevention of Juvenile Delinquency is the most important aspect of crime prevention in society. By engaging in legitimate, socially beneficial activities and developing a humanistic outlook on society and life, youth can be educated on principles that do not allow criminal activity ${ }^{17}$.

Minors have the same rights and freedoms as adults, as well as increased guarantees of their protection and protection by the state. The benefits of activities unrelated connected with isolation from society, are obvious and that these measures should be not only a warning but also an educational character.

Criminal Law is envisaging you a number of provisions, which contribute to the resocialization minor's no purpose of punishment. In addition, these provisions contribute to the implementation of the principle of the best interests of the child, enshrined in Art. 3 of the Convention on the Rights of the Child on 20 November 1989. As well as international obligations Ukraine, provided, in particular Minimum standard rules of the United Nations, which relate departure justice on juvenile (Beijing Rules) of 29.11.1985, The guiding principles of the UN to prevent crime among juveniles from 14 December 1990, Rules of the United Nations concerning the protection of minors, deprived of liberty on 14 December 1990, Guidelines of the Committee of Ministers of the Council of Europe on child-friendly justice from 17 November 2010 and practice the ECtHR (Case of V. v. the United Kingdom of 16 December 1999, Ichin and others v. Ukraine of 21 December 2010, Svershov v. Ukraine of 27 November 2008, etc.).

Particular attention in responding to juvenile misconduct should be given to restorative justice, which contributes to the reconciliation of the perpetrator with the victim and has a higher preventative effect on the juvenile's future behavior.

\footnotetext{
16 Дмитришина T.I. Призначення покарання неповнолітнім: концептуальні основи : дис. ... канд. юрид. наук : 12.00.08. Одеса, 2016. 205 с.

17 United Nations Guidelines for the Prevention of Juvenile Delinquency (The Riyadh Guidelines) A/RES/45/112 68th plenary meeting 14 December 1990. URL: https://resourcecentre. savethechildren.net/library/united-nations-guidelines-prevention-juvenile-delinquency-riyadhguidelines-ares 45112
} 
Restorative justice refers to any process which enables those harmed by crime, and those responsible for that harm, if they freely consent, to participate actively in the resolution of matters arising from the offence, through the help of a impartial third party.

Robinson, Paul H. as a practical matter, restorative processes are likely to generate results that track a principle of empirical desert: the empirical evidence is clear that ordinary people think about criminal liability and punishment in desert terms, but nothing in the restorative processes typically demands adherence to this or any other distributive principle ${ }^{18}$.

In the Preamble to the Recommendation № R (99) 19 of the Committee of Ministers concerning mediation in penal matters on 15 September 1999 stated that mediation may increase awareness of the important role of the individual and the community in preventing and handling crime and resolving its associated conflicts, thus encouraging more constructive and less repressive criminal justice outcomes ${ }^{19}$.

Pursuant to The Recommendation $\mathrm{CM} / \operatorname{Rec}(2018) 8$ concerning restorative justice in criminal matters was adopted by the Committee of Ministers on 3 October 2018 at the 1326th meeting of the Ministers' Deputies, the core principles of restorative justice are that the parties should be enabled to participate actively in the resolution of crime (the principle of stakeholder participation), and that these responses should be primarily oriented towards addressing and repairing the harm which crime causes to individuals, relationships and wider society (the principle of repairing harm) (p. 13). Other key restorative justice principles include: voluntariness; deliberative, respectful dialogue; equal concern for the needs and interests of those involved; procedural fairness; collective, consensus-based agreement; a focus on reparation, reintegration and achieving mutual understanding; and avoiding domination. These principles may be used as a framework with which to underpin broader reforms to criminal justice (p. 14). Restorative justice should not be designed or delivered to promote the interests of either the victim or offender ahead of the other. Rather, it provides a neutral

\footnotetext{
18 Robinson, Paul H. and Williams, Tyler Scot. Mapping American Criminal Law: variation across the 50 states: Chapter One: Distributive Principles of Criminal Law. (2018). Faculty Scholarship. 2002: 32. URL: https://scholarship.law.upenn.edu/faculty_scholarship/2002.

19 The Recommendation No. R (99) 19 of the Committee of Ministers to member States concerning mediation in penal matters (Adopted by the Committee of Ministers on 15 September 1999 at the 679th meeting of the Ministers' Deputies). URL: https:/www.barobirlik.org.tr/dosyalar/ duyurular/hsykkanunteklifi/rec(99)19\%20().pdf.
} 
space where all parties are encouraged and supported to express their needs and to have these satisfied as far as possible (p. 15) ${ }^{20}$.

The use of restorative and dialogic practices does not fit into the existing framework of Criminal Law, but at the same time contributes to the solution of problems that are not posed by classical justice. Those tasks whose solution is important in the context of European integration, especially for juvenile. Methods, which operates such a model capable of Justice, in particular to promote reconciliation perpetrator and the victim, reducing tensions between them, provide an opportunity to speak out and be heard, promote correct and compensate for damage; elimination of consequences caused by crime; enables to achieve the best balance of the interests of the victim and the responsibility of the offender.

According to European standards, minors are not subject to life imprisonment. At the same time, if the means of criminal influence against minors do not work, the likelihood of committing an adult crime for which life imprisonment is punished is much higher. In addition, there are certain European standards for life imprisonment.

\section{Prolonged deprivation of liberty and life imprisonment}

Prolonged deprivation of liberty, including life imprisonment, without a legitimate reduction procedure is not humane and is contrary to fundamental human rights in the meaning of the European Court of Human Rights (Case of Vinter and Others v. United Kingdom (applications no 66069/09, 130/10 i 3896/10) from 9 July.2013; Hutchinson v. The United Kingdom. (Application no 57592/08) from 17 January 2017 and other). The practice of replacing life imprisonment by deprivation of liberty in the form of pardon in Ukraine is not entirely consistent with the position of the ECtHR, in particular because there is no clear legal mechanism for reviewing the decision to impose a life imprisonment within a certain period of time. Consequently, there is a need to justify the mandatory review of life imprisonment within a certain period. It is necessary to harmonize Criminal Law with the practice of the ECtHR.

According to the practice the ECtHR in the Case of Del Río Prada v. Spain (application no 42750/09) from 21 October 2013 the sentence to sixteen people convicted of terrorism was reduced for work in prison, although they have been sentenced to a total of over 100 years in prison.

\footnotetext{
20 The Recommendation $\mathrm{CM} / \operatorname{Rec}(2018) 8$ concerning restorative justice in criminal matters was adopted by the Committee of Ministers on 3 October 2018 at the 1326th meeting of the Ministers' Deputies. URL: https://search.coe.int/cm/Pages/result_details.aspx?ObjectId=09000016808e35f3. 
Interpretation of law to the detriment of the convict was based on a policy of full implementation of sentences, not characteristic of the Criminal Code of 1973. Some judges felt that criminal political reasons in any case could not justify departure from the principle of legality, even if a terrorist and murderer who does not repent ${ }^{21}$. Whatever a serious crime is committed by a person, the law should provide for a procedure for shortening the term based on his (person) post-criminal behavior. Long term imprisonment, including life imprisonment, without a legal procedure for shortening the term, are not humane and contrary to fundamental human rights in the understanding of the ECtHR.

Some arguments should also be made regarding the humane nature of life imprisonment. Discussion about the «real» life imprisonment (ie a life sentence in which the convicted person is unable to ever in my life to be released) has a long history. The introduction into practice of this punishment has been the response of European states to the abolition of the death penalty under Protocols 6 and 13 to the European Convention on Human Rights. Since that time, does not stop the discussion about the punishment of life imprisonment without the right to further review it within the meaning of Article 3 of the Convention.

Pursuant to paragraph 9, 12 of the Council of Europe Resolution (76) 2 on the treatment of long-term prisoners (Adopted by the Committee of Ministers on 17 February 1976 at the 254th meeting of the Ministers' Deputies), review, of the life sentence should take place, if not done before, after eight to fourteen years of detention and be repeated at regular intervals ${ }^{22}$.

It is also worth mentioning the cases of Vinter v. The United Kingdom, (Application no 66069/09, 130/10 and 3896/10) from 09 July 2013, László Magyar v. The Hungary (Application no 73593/93) from 20 May 2014, Hutchinson v. The United Kingdom (Application no 57592/08) from 17 January 2017.

In the case of Vinter v. The United Kingdom the court interpreted Article 3, which requires a sentence of life imprisonment to be reviewed by a procedure allowing the domestic authorities to consider the legitimacy of the applicant's continued detention, given the importance of changes in his conduct. As Judge Power pointed out, Article 3 includes the right to hope.

\footnotetext{
21 Del Río Prada v. Spain, The European Court of Human Rights, 21 October 2013, application no 42750/09. URL: http://hudoc.echr.coe.int/eng?i=001-127697.

22 Council of Europe Resolution (76) 2 on the treatment of long-term prisoners (Adopted by the Committee of Ministers on 17 February 1976 at the 254th meeting of the Ministers' Deputies). URL: https://rm.coe.int/16804f2385.
} 
Hope is an important aspect of the human personality, and its deprivation denies the fundamental aspect of humanity and degrades the individual ${ }^{23}$.

In itself, imposing penalties for crimes committed by them in the form of life imprisonment is justified in all cases. The plaintiffs interpret their punishment as "inhuman or degrading treatment" according to Art. 3 of the Convention

The ECtHR has developed and applied criteria to identify possible violations of Article 3 of the Convention in such cases. Such violations can occur when duly proved that, firstly, continued serving plaintiff prison term cannot be justified by "legitimate penology grounds" and, secondly, the decision to appoint life imprisonment de jure and de facto makes it impossible to reduce it.

17 January 2017 the Grand Chamber of the European Court of Justice in case Hutchinson v. The United Kingdom, (Application no 57592/08) ${ }^{24}$ in fourteen votes to three, held that there had been no violation of Article 3 of the Convention (prohibition of inhuman or degrading treatment). The case concerned a complaint of the convict, who is serving a life sentence for the murder of three members of the family and rape fourth. The punishment, in his opinion, is cruel and degrading because he has no hope of release. Although the Convention does not prohibit the appointment sentenced life imprisonment for the most serious crimes such as murder, but in order to comply with the provisions of the Convention, it is necessary that prisoners have the opportunity to be released and to have their sentence reviewed. According to the practice ECtHR, the United Kingdom courts have eliminated ambiguity in life-time revision legislation. Contradictions between the law and the official policy of the United Kingdom, which the ECtHR referred to in its previous rulings, the United Kingdom Court of Appeal were removed a provision requiring the State Secretary of Justice to exercise its powers for release life prisoners in a manner relevant Convention requirements.

In addition, the Court of Appeal provided clarification on the limits and grounds for the revision of the sentence, the manner in which it should be carried out, and specified the duties of the Secretary of State for the release of life inmates when their further detention was no longer justified. The ECtHR considered the provisions of the legislation governing

\footnotetext{
${ }_{23}$ Case of Vinter and Others v. United Kingdom, The European Court of Human Rights (Grand Chamber), 9 July 2013, applications No. 66069/09, 130/10 and 3896/10. URL: http://hudoc.echr. coe.int/eng?i=001-122664.

24 Hutchinson v. United Kingdom, The European Court of Human Rights (Grand Chamber), 17 January 2017. applications no 5792/08. URL: http://hudoc.echr.coe.int/eng?i=001-170347.
} 
the revision of life sentences and concluded that life sentences in the United Kingdom are currently in compliance with Art. 3 of the Convention.

We also should consider the position of the ECtHR in case of Matiošaitis and Others v. Lithuania on complaints of inhumane treatment of eight Lithuanian nationals (Application no 22662/13, 51059/13, 58823/13, 59692/13, 59700/13, 60115/13, 69425/13 and 72824/13) sentenced to life imprisonment. Having considered the complaints of all eight applicants, the European Court of Human Rights found that the defendant country had indeed breached Article 3 of the Convention. This decision was made for six of the eight applicants: K. Matiošaitis, J. Maksimavičius, S. Katkus, V. Beleckas, A. Kazlauskas and P. Gervin.

ECtHR in the case of László Magyar v. Hungary (Application no 73593/93) from 20 May 2014 emphasizes the feasibility of considering the possibility of parole or serving a sentence of life imprisonment. The court declares the complaint concerning the applicant's whole life sentence and the length of the criminal proceedings admissible and the remainder of the application inadmissible; holds, that there has been a violation of Article 3 of the Convention; holds that the finding of a violation constitutes sufficient just satisfaction in respect of the violation of Article 3 of the Convention ${ }^{25}$.

If we analyze the practice of substitution of life imprisonment by imprisonment in Ukraine ${ }^{26}$, according to the provisions of Part 2 of Art. 87 CC of Ukraine, the act of President's pardon may be replaced by person sentenced by the court in the form of life imprisonment for a term of at least twenty five years.

Such a procedure is not in line with the ECtHR's position because punishment can only be imposed by a court. Pardon - an act of charity on one individual person, which is made by the President of Ukraine (not the court), life imprisonment cannot be mitigated; there is no clear legal mechanism for reviewing the decision on the imposition of life imprisonment after a certain period of time; national law does not guarantee a person the possibility of revising the decision on the imposition of life imprisonment with replacement of a milder sentence, reduction of the term of punishment, termination of serving of a sentence, parole (Kafkaris v. Cyprus, Vinter and Others v. UK, Öcalan v. Turkey).

\footnotetext{
25 László Magyar v. Hungary, The European Court of Human Rights, 20 May 2014, application no 73593/93. URL: http://hudoc.echr.coe.int/eng?i=001-144109.

26 Про Положення про порядок здійснення помилування: Указ Президента України № 223/2015 від 21.04.2015 p. URL: http://zakon2.rada.gov.ua/laws/show/223/2015.
} 
The possibility of substituting a punishment by an act of an administrative authority for a period of not less than 25 years does not correspond to the generally accepted principle of legality. Expedient to consider in the future the determination of a two-stage solution to this issue: pardoning the person by the president and replacing the sentence with the pardoned person solely by the court. This fully corresponds to the interpretation of the case law of the provisions of Article 7 of the Convention, according to which the court must check whether the act of state coercion is a punishment and that the sentence imposed does not exceed the prescribed limits (Coëme and Others v. Belgium, § 145; Del Río Prada v. Spain [GC], § 80) ${ }^{27}$.

So prolonged deprivation of liberty, including life imprisonment, without a legitimate reduction procedure is not humane and is contrary to fundamental human rights in the meaning of the ECtHR. Consequently, need to justify the mandatory review of life imprisonment within a certain period ${ }^{28}$.

One of the purposes of punishment is to prevent the commission of new crimes. In the context of life imprisonment, a person is isolated and therefore cannot commit other crimes. However, it is difficult to talk about the resocialization.

The punishment implements the principle of humanism in relation to third parties, since punishment provides a kind of security for them. The amendment reflects the realization of the principle of humanism in relation to the person who committed the crime; takes into account mitigating circumstances when sentencing; makes it possible to replace the punishment with a more lenient one if the conditions are met; parole and more. Preventing the commission of new crimes involves the manifestation of the implementation of the principle of humanism towards the victim and third parties, providing them with security.

The validity of the current prison system (based on observation results and statistics) does not contribute to correcting the perpetrator; does not promote (but does not aim to) compensate the injured person. That is, it seems that the current conditions of life imprisonment do not contribute to the achievement of the set goals.

The implementation of the principle of humanism in criminal law is aimed at applying sufficient and necessary punishment, taking into account

27 Tuliakov V.A. Criminal policy in East European Territories. Актуальні проблеми вітчизняної юриспрудениії. 2018. № 6. С. 193.

28 Тімофєєва Л.Ю. Гуманістична парадигма кримінального права України : автореф. дис. ... к.ю.н. : 12.00 .08 «Кримінальне право та кримінологія; кримінально-виконавче право». НУ ОЮА. Одеса, 2018. С. 15. 
the principles, objectives, tasks, functions of criminal law, methods of criminal law regulation; the punishment so severe as is appropriate to the nature and conduct of the person at the time of the crime; sociodemographic characteristics of a person; the nature of the harm caused to the victim, third parties and the state; other circumstances of the case, such as the nature and severity of the crime, and account for pre-criminal and post-criminal behavior.

It should be noted that the humanistic ideas implies a balance between the realization of the principle of humanism, both for the perpetrator and the victim, as well as for society as a whole and the state. In practice, the issue of notifying the victim about the use of the means of postcriminal promotion (in particular, release from criminal responsibility, parole, amnesty, pardon, etc.) is bypassed. The realization of the principle of humanism towards the victim can be regarded as compensation for his harm and restitution.

\section{CONCLUSIONS}

In the path of European integration Criminal law of Ukraine should take into account universal humanistic principles. These principles also laid down in the Association Agreement and the ECtHR's practices.

According the practice of ECtHR, the law is humanistic, fair and in accordance with the principles of Criminal Law when it complies with the provisions of the Convention. Therefore, it should reflect the list of socially dangerous acts that violate human rights as defined in the Convention.

The use of restorative and dialogic practices does not fit into the existing framework of Criminal Law, but at the same time contributes to the solution of problems that are not posed by classical justice. Those tasks whose solution is important in the context of European integration, especially for juvenile. Methods, which operates such a model capable of Justice, in particular to promote reconciliation perpetrator and the victim, reducing tensions between them, provide an opportunity to speak out and be heard, promote correct and compensate for damage; enable subject a role to play in addressing the important issues in their lives; elimination of consequences caused by crime; enables to achieve the best balance of the interests of the victim and the responsibility of the offender.

In the context of European integration, in addition to the classicinstruments of counteraction to crime (reaction to crime) (for crime - punishment), it is advisable to develop restorative, dialogical practices, practices of nonviolent communication. 
Prolonged deprivation of liberty, including life imprisonment, without a legitimate reduction procedure is not humane and is contrary to fundamental human rights in the meaning of the European Court of Human Rights. The practice of replacing life imprisonment by deprivation of liberty in the form of pardon in Ukraine is not entirely consistent with the position of the ECtHR, in particular because there is no clear legal mechanism for reviewing the decision to impose a life imprisonment within a certain period of time. Consequently, need to justify the mandatory review of life imprisonment within a certain period.

\section{SUMMARY}

The article sets out the results of a research some issues of European integration in the modern Criminal Law of Ukraine. In today's changing conditions, classical models (crime - punishment) do not lead to effective results in prevention of crimes. Criminal law causes pain. In the context of European integration, in addition to the classic instruments of reaction to crime (for crime - punishment), it is advisable to develop restorative, dialogical practices, practices of nonviolent communication. Additionally, the article covers that in the European Court of Human Rights view, the law is humanistic, fair and in accordance with the principles of Criminal Law when it complies with the provisions of the Convention. The article substantiates the conclusion that the practice of replacing life imprisonment by deprivation of liberty in the form of pardon in Ukraine is not entirely consistent with the position of the ECtHR, in particular because there is no clear legal mechanism for reviewing the decision to impose a life imprisonment within a certain period of time. Consequently, need to justify the mandatory review of life imprisonment within a certain period.

\section{REFERENCES}

1. Albrecht, Peter-Alexis. The Forgotten Freedom: September 11 as aChallengeforEuropeanLegalPrinciples. Berlin :BWVBerlinerWissenschaftsVerlag, 2003.

2. Баулин Ю.В. О методологическом подходе к определению уголовной ответственности (на материалах Украины). Российский ежегодник уголовного права. 2012. № 6. С. 480-489.

3. Коэн-Элия М., Порат И. Американский метод взвешивания интересов и немецкий тест на пропорциональность: исторические корни. Сравнительное конституционное обозрение. 2011. № 3. С. 59-81.

4. Дмитришина T.I. Призначення покарання неповнолітнім: концептуальні основи : дис. ... канд. юрид. наук : 12.00.08. Одеса, 2016. 205 c. 
5. Engle, E. The History of the General Principle of Proportionality: An Overview. Dartmouth Law Journal. № 10. 2012. P. 1-11. URL: http://papers.ssrn.com/sol3/papers.cfm?abstract_id=1431179.

6. Filippov, S.O. The smuggling of tobacco product in Europe: criminologetic potential capacity. Baltic Journal of Law \& Politics. 2019. № 12 (1). P. 35-61. DOI: 10.2478/bjlp-2019-0002

7. Mowbray, A. A Study of the Principle of Fair Balance in the Jurisprudence of the European Court of Human Rights. Human Rights Law Review, Volume 10, Issue 2. 2010. P. 289-317. DOI: 10.1093/hrlr/ngq006.

8. Погребняк С. Принцип пропорційності у судовій діяльності. Філософія права і загальна теорія права. 2012. № 2. С. 49-55.

9. Robinson, P.H. and Williams, T.S. Mapping American Criminal Law: variation across the 50 states: Chapter One: Distributive Principles of Criminal Law. Faculty Scholarship. 2002. URL: https://scholarship.law.upenn.edu/ faculty_scholarship/2002.

10. Шлинк Б. Пропорциональность: к проблеме баланса фундаментальных прав и общественных целей. Сравнительное конституиионное обозрение. 2012. № 2 (87). С. 56-77.

11. UNDP. Institute for Economics \& Peace. Global Terrorism Index 2019: Measuring the Impact of Terrorism. Sydney. 2019. URL: http://visionofhumanity.org/reports (accessed Date Month Year).

12. Тімофєєва Л.Ю. Гуманістична парадигма кримінального права України : автореф. дис. ... к.ю.н. : 12.00 .08 «Кримінальне право та кримінологія; кримінально-виконавче право». НУ ОЮА. Одеса, 2018. 23 с.

13. Timofeyeva, L.Yu. European integration Criminal Law policy and achievement freedom and security: collective monograph. Law and Border: Implementation of law policy in the sphere of state border security / N. Orlovska, A. Mota, R. Liashuk, L. Timofeyeva, L. Litvin. Lviv-Toruń : Liha-Pres, 2019. P. 50-67. DOI https://doi.org/10.36059/978-966-397-179-7/50-66.

14. Tuliakov V.A. Criminal policy in East European Territories. Актуальні проблеми вітчизняної юриспрудениії. 2018. № 6. С. 191-194.

15. Council of Europe Resolution (76) 2 on the treatment of long-term prisoners (Adopted by the Committee of Ministers on 17 February 1976 at the 254th meeting of the Ministers' Deputies). URL: https://rm.coe.int/16804f2385

16. United Nations Guidelines for the Prevention of Juvenile Delinquency (The Riyadh Guidelines) A/RES/45/112 68th plenary meeting 14 December 1990. URL: https://resourcecentre.savethechildren.net/library/united-nationsguidelines-prevention-juvenile-delinquency-riyadh-guidelines-ares 45112

17. United Nations Standard Minimum Rules for the Administration of Juvenile Justice (The Beijing Rules) Adopted by General Assembly 
resolution 40/33 of 29 November 1985. URL: https://www.un.org/ruleoflaw/ files/UNAdminofJJUSTICE.pdf

18. The provisions on the procedure for the implementation of the pardon : Presidential Decree Ukraine no 223/2015 of 21 April 2015. URL: http://zakon2.rada.gov.ua/laws/show/223/2015.

19. The Recommendation No. R (99) 19 of the Committee of Ministers concerning mediation in penal matters. URL: https://www.barobirlik.org.tr/ dosyalar/duyurular/hsykkanunteklifi/rec(99)19\%20().

20. The Recommendation $\mathrm{CM} / \operatorname{Rec}(2018) 8$ concerning restorative justice in criminal matters was adopted by the Committee of Ministers on 3 October 2018 at the 1326th meeting of the Ministers' Deputies. URL: https://search.coe. $\mathrm{int} / \mathrm{cm} /$ Pages/result_details.aspx? ObjectId=09000016808e35f3.

21. Case of Hutchinson v. United Kingdom, The European Court of Human Rights (Grand Chamber), 17 January 2017. applications no 5792/08. URL: http://hudoc.echr.coe.int/eng?i=001-170347.

22. Case of Vinter and Others v. United Kingdom, The European Court of Human Rights (Grand Chamber), 9 July 2013, applications No. 66069/09, 130/10 and 3896/10. URL: http://hudoc.echr.coe.int/ eng? $\mathrm{i}=001-122664$.

23. Case of László Magyar v. Hungary, The European Court of Human Rights, 20 May 2014, application no 73593/93. URL: http://hudoc.echr.coe.int/ eng?i=001-144109.

24. Case of Maktouf and Damjanović v. Bosnia and Herzegovina, The European Court of Human Rights, 18 July 2013, applications no 2312/08 and 34179/08. URL: http://hudoc.echr.coe.int/sites/eng/pages/search. aspx? $\mathrm{i}=001-12271$.

25. Case of Saunders v. the United Kingdom, The European Court of Human Rights, 17 December 1996, application no 19187/91. URL: http://hudoc.echr.coe.int/eng?i=001-58009.

26. Case of Funke v. France, The European Court of Human Rights, 25 February 1993, application no 10828/84. URL: http://hudoc.echr.coe.int/ eng? $\mathrm{i}=001-57809$.

\section{Information about author: Timofeyeva L. Yu., Ph.D.,}

Assistant Professor of Criminal Law Department National University "Odesa Law Academy" 23, Fontanska dor. str., Odesa, Ukraine DOI https://doi.org/10.30525/978-9934-588-43-3/2.22 